\title{
AUDIO-VISUAL METHOD IN THE PROCESS OF TEACHING ENGLISH ON THE BASIS OF THE INTERNET RESOURCES
}

\begin{abstract}
The article presents the usage of the most usable during classes audio-visual method in the process of teaching English. The authors emphasize its benefits and positive tendency in the educational process. It is also mentioned about the modernization of this method of teaching due to modern equipment and technology and its practical usage. The authors underline that the use of the audio-visual method raises interest in learning by creating special conditions for the language environment. This method gives the opportunity to make the lesson informative, extraordinary, up to date and to expand the ways of transferring knowledge from the teacher to the student in easy, clear and high-quality way. The use of multimedia presentations, as one of the techniques of the audio-visual method, is a way of including a student in the learning process, the way in which his or her speech and communicative competence is developed, depending on the tasks set by the teacher. The second part of the article is devoted to the use of the Internet resources as the source of realization audio-visual method in the process of teaching English. The authors attention is focused on the advantages of the Internet platform "ELLLO" or "English Listening Lesson Library Online" for the developing phonological competence where you can find four links for audios, videos, products and courses, advanced search. There can be found study plans according to the level of English and one minute videos that can be used during classes. The authors emphasize that the usage of the platform can be applied in combination with any educational materials and textbooks. The ability of observing people from more than 300 countries gives the opportunity to compare different accents, listen to native speakers. It is especially necessary for the teachers- to-be students of faculties of foreign languages.
\end{abstract}

Key words: audio-visual method, foreign languages study, multimedia presentation, direct methods, visual component, phonogram, website, video, audio, the Internet, platform, user.

\section{(статтю подано мовою оригіналу)}

The problem of the creation and application of new methods are also being discussed today. Such scientists as G. Barabanova, M. Klymyuk, O. Nikitina are working in this field.

One of the most significant and wide-spread method is the audio-visual method. Technological progress and the development of technologies have made it possible to maximize the benefits of this method during the process of learning a foreign language. In recent years, in the methodological literature, there are often publications that describe the use of the audiovisual method. This question is highlighted in the works of G. Borgiv, O. Hromova, T. Venieri, and J. Ferson, E. Dale and others.

Aim of research. However, teachers often underestimate the audio-visual method during their teaching activity and therefore do not use it, or use it very rarely. These problems can be solved by informing about the advantages of its usage and feasibility.

The audio-visual method cannot be considered a linguistic or methodological miracle of our time: it is a reflection of the most important achievements of modern linguistics and methodology of teaching of foreign languages. The method arose in France in the 50 years of XX century. His representatives were P. Guberin (Yugoslavia), P. Rivan, R. Michea, J. Gugenheim, A. Sauagio (France). The method retains all the basic principles of direct methods: global perception of linguistic material by ear; native language is completely excluded from the learning process; the main ways of learning are the simulation, learning by heart the phrases and the formation of phrases by analogy. The purpose of the audio-visual method is the practical mastery of the linguistic material for everyday communication [1].

The modern audio-visual method has risen to a higher level and somewhat modified. The particularity of the modern audio-visual method is that its implementation is based on the scientific selection of material and the intensive use of information technology training. Also, access to the Internet has led the audio-visual method to a new stage of development. A teacher can find the necessary material, create the tasks and do them with the students.

The advantage of the audio visual method of teaching is that it helps to create the necessary conditions for the language environment, close to the natural, in which a language exists. This method is of high interest because it allows you to go beyond the traditional teaching of a foreign language, promotes the rapid formation of elements of spontaneous speech, gives students the possibility to familiarize themselves with the peculiarities of life and culture of native speakers. And this, in turn, raises the interest of students in language acquisition and accelerates this process.

The special organization of the pedagogical process ensures repetition of speech structures and their active use in prepared situational exercises. In the audio-visual method of synthesizing the material perceived by the ear, a phonogram is a priority. Regarding the place of the visual component, this aspect needs more detailed consideration in the implementation of the audiovisual method [2].

For the audio-visual method, the maximum loading of the visual channel is the reception of information simultaneously with the auditory. Thanks to this the formation of stable associations is expected, and we can speak about the automaticy in mastering the structures of language.

The initial stage of using the audio-visual method is the development of oral speech. The task of spoken language is to provide students with the ability to use a foreign language in everyday communication with native speak- 
ers. The name of the method involves the mechanism of its use. The new material is perceived by students only by hearing (audio), and its value is revealed through visual non-verbal visualization.

This method is also called structural-global, since language learning takes place on the basis of specially selected structures that are perceived holistically (globally) [3]. Representatives of the audio-visual method attach exclusive importance to topics that cover the situations of everyday communication that are revealed in special videos. In such educational films, characters conduct a specific thematic conversation on the topic of real life. They introduce students not only the linguistic material but also the situations in which they are used. The dialogues are perceived as a whole.

The Principle of Audio Visual Method

- selective;

- preparation;

- physical control;

- proper presentation;

- response.

One example of using the audio-visual method when learning a foreign language is the use of multimedia presentations in the lesson. However, one should not forget that this cannot be a substitution for live communication at the lesson. It can only be a stimulus to fruitful work and a means of increasing interest in language learning. New multimedia tools that use audio-visual format provide opportunities that cannot be realized through traditional textbooks.

The use of information technology during the classroom expands the possibilities of choosing materials and ways of presenting it, explaining it, and consolidating it. The use of the audio-visual method raises interest in learning and stimulates active activity. This method gives the opportunity to make the lesson modern, extraordinary, informative and to expand the ways of transferring knowledge from teacher to student. The use of multimedia presentations, as one of the techniques of the audio-visual method, is a way of including a student in the learning process, the way in which his or her speech and speech competence is developed, depending on the tasks set by the teacher.

The audio-visual method activates two channels of perception of information at once: hearing and visual. They increase the efficiency of its assimilation. The audio- visual method is one of the leading methods in forming the phonological competence.

Phonological competence is simply one's underlying knowledge of the phonology of the linguistic system. In other words, it's the knowledge a speaker has as to how to correctly pronounce words - even those never used before-, how to understand another speaker's phonetic realizations (i.e. how to interpret phonologically another speaker's production), how to correctly assign stress, how to correctly deploy intonation patterns and how to interpret them upon hearing them (for ex. how to make or tell the difference between a statement and a question of the type: It's gone. v It's gone?). This knowledge of course implies not only the knowledge of the phonemes (essential phonological units) of the language but also the way these phonemes are actually realized phonetically, according to their distributional patterns (for ex. the phoneme / $\mathrm{p} /$ in English is phonetically realized differently according to whether it occurs before a stressed vowel or not - aspirated if before a stressed vowel, non-aspirated before a non-stressed vowel).

The formation of phonological competence plays a great role in the development of foreign communicative competence as it deals with the consecutive and purposeful formation of the pronunciation bases of each type of speech activity. We are to develop a system of exercises which helps to form phonological competence. It is up to each teacher to some exercises each of which corresponds to a specific stage of phonological competence formation. The developed system of phonological competence teaching allows realizing the stage-approach to the formation of each phonological competence component in other types of speech activity: listening, reading, speaking and writing. That is why it is obligatory to have as much as possible sources with audio and video exercises. Thanks to Todd Beuckens nowadays we are privileged to use free online exercises on his platform called "ELLLO" or "English Listening Lesson Library Online".

ELLLO is an online collection of free listening, reading, and vocabulary practices for English language learning. The resources on the website are Creative Commons - teachers and students can use the audio, videos, lessons, games, and quizzes for free. You do not need an account to access the resources. There is also an option to purchase a thousand downloadable mp3s files [10].

Todd Beuckens is the creator of the website "elllo.org". At present he works as an English teacher in Japan. Each week he publishes two new, free listening lessons. He has been teaching English for over twenty years and has taught in Thailand, Taiwan, and Japan. Mr. Beuckens created "elllo.org" in 2003 as part of a MA TESOL graduate school project. Since then, "elllo" has published more than 2,500 free activities featuring more than 300 speakers from over 100 countries. Students can use the site to practice English by working on listening, reading, vocabulary and even pronunciation and speaking. New lessons are published each Monday. Elllo is free and he creates it in his spare time because he is a full-time teacher. Even though the website is always in the process of modernization. The aim of the site it to make learning English fun, effective, and free and to provide teachers and students with materials that you cannot find in traditional textbooks.

Here is an example of how ELLLO fits the SAMR model:

- Substitution: Learners can practice using the website exercises instead of worksheets.

- Augmentation: ELLLO offers learners a variety of accents and stories from all over the world, which enhances traditional textbook-based learning. 
- Modification: Learners can customize their own learning plan. They can select the level they are interested in and the type of activities that can help them improve listening skills and vocabulary.

- Redefinition: All sources are creative commons, therefore students and teachers can adapt and remix the materials.

The homepage of the "English Listening Lesson Library Online" is very simple in using. You can find there four links for audios, videos, products and courses, advanced search. There are also presented study plans according to the level of English and one minute videos that are downloaded every day. It is very convenient for each user that there is always the author and his provenance denoted.

Views: This category includes natural conversations about several topics. Users can select them according to country, topic or level. There is an option for curated lists according to level. Check out this example on a conversation about Japanese Culture.

Mixer: This section collects 6 people from different countries answering to one question. You can check this example in which people from Canada, Mexico, and England share their opinions about the heroes they look up to.

Games: Games help contextualize the conversations. Users have to listen to a piece of a conversation, read a question, and pick up the corresponding image. Check this game about aquarium animals.

Videos: Maybe one of my favorite activities is one-minute videos that feature stories from speakers from around the world. A transcript and a quiz are included, sometimes a printable worksheet is also available [11].

Conclusions. To sum up, we can draw to conclusion that audio-visual method is becoming more and more used nowadays. The teachers can find various materials on the Internet. This simplifies their preparation, makes the process of conducting lessons more interesting and informative and motivate students. Such educational platforms as "Elllo" give the opportunity for the self-education. It simplifies the whole act of studying language both for the teachers and students.

\section{References:}

1. Artemenko L. Search for new technologies of English language teaching. New Collegium. 2002. No. 6. P. 16-20.

2. Aggarwal, J. C. Principles, Methods \& Techniques Of Teaching. India : Vikas Publishing House Pvt Ltd, India. 2009.

3. Dale, Edgar. Audio-Visual Methods in Teaching. Revised edition. New York : The Dryden Press, 2006. 534 p.

4. Freeman D. L. Techniques and Principles in Language Teaching. Oxford : Oxford Univ. Press, 2009. 142 p.

5. Gilliland, B. (2015). Listening logs for extensive listening practice. Language Learning Beyond the Classroom, 13.

6. Matviyenko I. V. Different methods in the classes of foreign language as a means of intensifying learning. URL: http://osvita.ua/ school/lessons_summary/education/45122/. Title from the screen.

7. McCaughey. Practical Tips for Increasing Listening Practice Time. In English Teaching Forum, 53. 2015.

8. Sinha, G. Connecting Lives Inside and Outside the Classroom: Why and How to Implement Technology in the Language Learning Classroom. World Academy of Science, Engineering and Technology, International Journal of Social, Behavioral, Educational, Economic, Business and Industrial Engineering, 10(3). 2016. P. 824-827.

9. URL: https://ekayantipt.wordpress.com/2012/06/07/audio-visual-method/.

10. URL: http://www.elllo.org/index.htm.

11. URL: https://blogs.umass.edu/onlinetools/knowledge-centered-tools/elllo-english-listening-lesson-library-online/.

Біленька Ю. О., Коломісць М. М. Використання інтернет-ресурсів під час застосування аудіо-візуального методу в процесі навчання англійської мови

У статті представлено інтерактивний метод мозкового штурму як однієї з найефективніших стратегій для генерації ідей на задану тему. Автори описують етапи мозкового штурму. У статті подаються поради вчителю для ефективної організації та застосування цьього методу під час різних етапів уроку. Увага авторів зосереджена на перевагах такого виду діяльності. Також у статті згадується про теорію Алекса Осборна та зв 'язок мозкового штурму із процесом розвитку творчого мислення.

У статті представлено використання найбільш корисного під час занять аудіовізуального методу в процесі викладання англійської мови. Автори підкреслюють його переваги та позитивну тенденцію у навчальному процесі. Також згадується про модернізацію иього методу навчання за рахунок сучасного обладнання та технологій та його практичного використання. Автори підкреслюють, щь використання аудіовізуального методу викликає інтерес до навчання, створюючи особливі умови для мовного середовища. Цей метод дає можливість зробити урок інформативним, неординарним, сучасним та розширити шляхи передачі знань від вчителя до учня простим, зрозумілим та якісним способом. Використання мультимедійних презентацій як одного з прийомів аудіовізуального методу є способом включення учня у навчальний проиес, способом розвитку його мовленнєвої та комунікативної компетениї залежно від завдань, поставлених вчителем. Друга частина статті присвячена використанню Інтернет-ресурсів як джерела реалізаиї аудіовізуального методу в процесі навчання англійської мови. Увага авторів зосереджена на перевагах Інтернет-платформи «ELLLO» або «Бібліотеки уроків англійської мови онлайн» для розвитку фонологічної компетентності, де ви можете знайти чотири посилання на аудіо-, відео-курси та розширений пошук. Тут можна знайти плани навчання відповідно до рівня англійської мови та однохвилинні відеоролики, які можна використовувати під час занять. Автори підкреслюють, щчо використання платформи можна застосовувати в поєднанні з будь-якими навчальними матеріалами та підручниками. Можливість спостерігати за людьми з понад 300 краӥн дає можливість порівнювати різні акценти, слухати носіїв мови. Це особливо необхідно для майбутніх викладачів факультетів іноземних мов.

Ключові слова: мозковий штурм, вирішення проблем, інтерактивні методи, генерування ідей, творче мислення, метод проектів. 